\title{
The impact of reduced graphene oxide on the properties of polyamide 6
}

\author{
Maziyar Sabet ${ }^{1), *)}$ (ORCID ID: 0000-0001-6192-5195), Seyednooroldin Hosseini ${ }^{2)}$ (0000-0003-2108-6256)
}

DOI: dx.doi.org/10.14314/polimery.2021.4.2

\begin{abstract}
Polyamide 6 (PA6) nanocomposites with electric and thermal conductive properties were formulated via melt processing of PA6 and different inclusion of reduced graphene oxide (RGO). These nanocomposites showed that the small percolation threshold and the perfect formation of conductive link form with $0.5 \mathrm{wt} \%$ and $\sim 3.0 \mathrm{wt} \%$ of RGO, respectively. Examination of crystallization confirmed that RGO enabled the crystallization of PA6 structure mostly through speeding up the formation of crystal nucleus, reaching the biggest and the smallest of crystal grain extent with RGO inclusion up to $2.0 \mathrm{wt} \%$ what enabled the generation of the most unflawed crystalline matrix. Dynamic rheological testing results indicated the frequency-independence of $G^{\prime}$ and abruptly decrease phase angle at the small-frequency area via RGO content of $2.0 \mathrm{wt} \%$ specifies the alteration state from liquid-state to solid-state rheological performance, and validates the development of percolation link structure with RGO in the function of a crosslinking factor. The progress of fire-retardant characteristics of PA6 was attained due to the inclusion of RGO in the PA6 structure. Morphological research showed that RGO was spread consistently in the PA6 structure. The outcomes of cone calorimetry showed that the flame-retardant characteristics of PA6 were promoted with the addition of RGO in the PA6 structure. These tests show substantial capacity for the bulk manufacture of electric conductive polymer/RGO nanocomposites.
\end{abstract}

Keywords: reduced graphene oxide, polyamide 6, nanocomposites, characterizations, melt-blending.

\section{Wpływ zredukowanego tlenku grafenu na właściwości poliamidu 6}

Streszczenie: Na bazie poliamidu 6 (PA6), przetwarzanego w stanie stopionym z dodatkiem różnej ilości zredukowanego tlenku grafenu (RGO), otrzymano nanokompozyty charakteryzujące się przewodnictwem elektrycznym i termicznym. Nanokompozyty o zawartości $0,5 \%$ mas. RGO wykazywały niski próg perkolacji, a próbki o zawartości $3 \%$ mas. GRO - doskonale utworzoną fazę przewodzącą. Badania potwierdziły, że dodatek do PA6 2,0\% mas. RGO umożliwił krystalizację struktury PA6, głównie w wyniku przyspieszenia tworzenia się jądra krystalicznego, i osiągnięcie zarówno największych, jak i najmniejszych wymiarów ziaren krystalicznych, co pozwoliło na utworzenie maksymalnie bezbłędnej matrycy krystalicznej. Wyniki dynamicznych testów reologicznych wskazały na niezależność modułu elastyczności $\left(G^{\prime}\right)$ od częstotliwości i na gwałtowne zmniejszenie kąta fazowego w obszarze małej częstotliwości w wypadku próbek nanokompozytów o zawartości RGO 2\% mas., typowe dla zmian właściwości reologicznych przy przejściu ze stanu ciekłego do stanu stałego i potwierdzające rozwój struktury połączeń perkolacyjnych PA6 z RGO, pełniącym funkcję czynnika sieciującego. Włączenie do struktury PA6 zredukowanego tlenku grafenu przyczyniło się do polepszenia właściwości ogniochronnych otrzymanych nanokompozytów. Ocena morfologii próbek nanokompozytów wykazała, że cząstki RGO rozproszyły się równomiernie w strukturze PA6. Na podstawie wyników kalorymetrii stożkowej stwierdzono uniepalniający wpływ dodatku RGO do PA6. Wykazano, że opisaną metodą można otrzymywać na skalę masową przewodzące prąd nanokompozyty PA6/RGO.

Słowa kluczowe: zredukowany tlenek grafenu, poliamid 6, nanokompozyty, charakterystyka, mieszanie $\mathrm{w}$ stanie stopionym.

\footnotetext{
1) Petroleum and Chemical Engineering, Universiti Teknologi Brunei (UTB), Jalan Tungku Link, Mukim Gadong A, BE1410 Bandar Seri Begawan, Brunei Darussalam.

2) EOR Research Center, Department of Petroleum Engineering, Omidiyeh Branch, Islamic Azad University, Omidiyeh, Khuzestan, Iran.

*) Author for correspondence: maziyar.sabet@utb.edu.bn, mazyiar_sabet@yahoo.com
} 
Polyamide 6 (PA6) is a conventional industrial polymer with superior mechanical resistance, outstanding load-bearing ability, strength to chemicals, greater selflubricating implementation, etc. [1-3], which enables PA6 to be employed broadly in engineering. Particularly, it is appropriate for substituting metallic substances for the fabrication of gears, bearings, and slide blocks [4-6]. For PA6, the span of exterior electrical resistivity is from $10^{12} \Omega$ to $10^{14} \Omega$ [7-9], that simply leads to the formation of static charge on the exterior sides, together with dust defect, short circuit, and causes a flame or a blast [10] in the zone of fiery, mining apparatus, a box of electrical tools, etc. Consequently, developed antistatic and fire-retardant characteristics are required to extend the range of PA6 applications. Graphene $(\mathrm{Gr})$, was taken into account because of interesting and incomparable physical characteristics [11-13]. Hence, Gr was underlined in assembling several micro-electrical tools [14], batteries [15], particularly in the area of conductive switching [16], bio-imaging [17], and photocatalysis [18], and one of the utmost intriguing features of $\mathrm{Gr}$ is the capacity for their usage in electronic purposes [19-21]. Gr was considered due to the very proficient thermal interface material, significant thermal regulator substance, and conductive alternate additive in nanocomposites, thanks to its excellent thermal conductivity $(k)$ and superior steadiness in elevated temperature [22]. Graphite oxide (GO), obtained through graphite oxidation, is a widely examined start-off substance for bulk production of Gr nano-layers [22]. It was confirmed that GO is easily dispersive in polymers which are soluble in water to boost their mechanical characteristics [23-25]. However, to obtain electric conductive polymer nanocomposites, a reduction in GO inclusion is required to eliminate the majority of its oxygen-containing chemical groups and reconstruct the graphitic link of $s p 2$ links $[26,27]$. To date, there are two efficient reduction methods, chemical and thermal reduction [28, 29] for the formulation of electric conductive polymer nanocomposites from graphite oxide. In organic solvents, warming GO suspensions considerably decrease the GO platelets with no reduction chemical factors [30, 31]. Consequently, these conductive nano-layers are employed to formulate conductive polymer nanocomposites through melt compounding [32]. Nevertheless, before the inclusion of a reducing chemical factor, the functionalization of GO nano-layers is required to prevent their coagulation which stabilizes its spread in organic solvents and polymer structures [33]. The inadequate oxidation and exfoliation of graphite oxide and heterogeneous spread of Gr sheets cause small electric conductivities [34]. Furthermore, the chemical reduction has drawbacks of usage of huge volumes of organic solvents and reduced fitting with numerous industrial processing procedures [35-37]. Reduced graphene oxide (RGO), based on the bulk fabrication on an engineering level, is decreased as the thermal treatment at temperatures to $1055^{\circ} \mathrm{C}$. Oxygen chemical groups on RGO surfaces were hard to be eliminated throughout the reduction process of
GO to RGO, and hence bond in the RGO was unavoidably affected by the oxygen chemical groups. Though, the reactive spots of oxygen chemical groups on the PA6 surface were simple to be created and regulated to attain a tailored interface by covalent linkage. Because of the influence of double bonds and atoms of $\mathrm{N}, \mathrm{O}$ on either hand of carbon atoms, the isocyanate group has extreme reaction activities and is simple to respond with nanocomposites holding active hydrogen [5-7]. Conversely, the consistent spread and the appropriate interface interaction among Gr and polymer structures look to be the block via straight mixing methodologies. The mechanically noncovalent blending, for instance, usually causes inadequate Gr spread and inadequate interface interaction in nanocomposites. Lately, though the organizations of thermal conductive nanocomposites were studied by the functionalization of Gr with polymers [11-13], in contrast, extra characteristics (electrical and mechanical characteristics), the thermal characteristics of Gr-based nanocomposites have taken minimum consideration, particularly the $k$ of nanocomposites of thermoplastics [15]. In this research, we aimed at increasing the $k$ of Gr-based PA6 composite to comprehend its thermal conductive functions. The obtained PA6 composite with elevated $k$ could be utilized in thermal interface substances, connectors, and other superior-behavior thermal management systems. In this study, the consistent spread of the RGO, through the melt processing, in the PA6 structure with superior melt viscosity in processing makes a quick growth of electric conductivity of nanocomposites with a small threshold percolation. Finally, electric conductive characteristics of the nanocomposites were researched, intending to the insight into the development mechanism of the percolation link structure. RGO and PA6 matched in polarity that conveys great electrical conductivity to PA6 polymer thanks to properly spread the electric conductive link of RGO nano-layers. Besides that, a profound understanding of the character of RGO in crystallization and movement/distortion histories of PA6 molecular links was identified. We demonstrate a novel strategy to boost the fire-retardant characteristics of PA6 by the inclusion of RGO. Gr is developing in the area of fire-retardant applications because of its endothermic and strong structure. Therefore, the combination of RGO into the polymer structure may be considered as an efficient method to get good fire-retardant characteristics in polymer and depicts a promising novel nanocomposites in engineering fabrications.

\section{EXPERIMENTAL PART}

\section{Materials}

RGO granules were prepared by Sixth Element Materials Technology Co., Ltd., (Changzhou, China) with a median size of 55 micrometer. The PA6 pellets (Taiwan Libaolon Co., Ltd.), were applied with no extra distillation and action. 


\section{Preparation of PA6-RGO nanocomposites}

Each specimen was conveniently dehydrated in vacuo at $85^{\circ} \mathrm{C}$ overnight before usage. Then the required proportion of RGO was blended and melt-mixed with PA6 in Thermo-Haake Rheomix with the temperature alterations of $225-255^{\circ} \mathrm{C}$ at a screw speed of $85 \mathrm{rpm}$. Subsequently, the blend fed out of the batch blender was quickly chilled to $25^{\circ} \mathrm{C}$, milled into granules, compression-molded for almost 6 minutes at $255^{\circ} \mathrm{C}$, and lastly, break into samples for supplementary categorizations.

\section{Methods of testing}

Thermogravimetric and differential thermal gravimetry tests (TGA-DTG) for specimens were demonstrated on a Perkin-Elmer Diamond thermal tester from $25^{\circ} \mathrm{C}$ to $800^{\circ} \mathrm{C}$, applying a warming proportion of $20^{\circ} \mathrm{C} / \mathrm{min}$ with $\mathrm{N}_{2}$ in the role of a specimen remove gas. Thermal conductivity (TC) was assessed "through-plane" technic with a Netzsch LFA 447 Nano-flash at $20^{\circ} \mathrm{C}$. A heat releasing test was demonstrated on a cone calorimeter analyzer (UK, warming $40 \mathrm{~kW} / \mathrm{m}^{2}$ ) according to the ISO 5660-1 technique. Differential scanning calorimetry (DSC) findings were measured on a Mettler Toledo TGA/DSC 1 tester in the $\mathrm{N}_{2}$ atmosphere and with a warming ratio of $15^{\circ} \mathrm{C} / \mathrm{min}$. Fourier transform infrared spectroscopy (FT-IR) was tested, applying a Nicolet Magna-IR 750 spectrometer over the wave number scale of $4000-400 \mathrm{~cm}^{-1}$. $X$-ray diffraction (XRD) patterns were investigated on an Inel Equinox 3000 diffractometer with $\mathrm{CuK}$ radiation source, conducted at $30 \mathrm{kV}$ and $35 \mathrm{~mA}$. Scanning electron microscopy (SEM) was investigated on a KYKY-EM3200 digital scanning electron microscope with a voltage of $25 \mathrm{kV}$. Specimens were cracked cryogenically in the liquid $\mathrm{N}_{2}$ and afterward covered with Au through vapor decomposition (KYKY SBC-12 ion sputtering coater) for SEM experiments. Transmission electron microscopy (TEM) testing was accompanied by employing of a JEOL JEM-2100 instrument with an acceleration voltage of $100 \mathrm{kV}$. The specimens were trickled on a copper grid for TEM characterization. Raman spectra (RS) were measured on a confocal Renishaw through the Raman microscope at $25^{\circ} \mathrm{C}$. The method was carried out with a CCD sensor and a holographic notch filter, applying an excitation wavelength of $535 \mathrm{~nm}$. Scans were attained from 900-3600 $\mathrm{cm}^{-1}$, demonstrating maps of 26 spectra on specimen granules. The electric conductivity of PA6 and PA6-RGO nanocomposites were calculated with a Keithley Instruments 2400 source meter (USA) when conductivity was greater than $10^{-6} \mathrm{~S} / \mathrm{m}$, while a ZC36 superior insulation resistance spectrometer (China) was applied once resistivity became lesser than $10^{-6} \mathrm{~S} / \mathrm{m}$. The thermal conductivity of PA6 and PA6-RGO nanocomposites was determined from thermal diffusivity that was calculated by employing a Netzsch LFA 447 device. Rheological analysis of PA6 and PA6-RGO nano- composites was taking place at $250^{\circ} \mathrm{C}$ on a rheometer (TAAR2000ex, USA) with a $25 \mathrm{~mm}$-parallel plate in a frequency range of $0.1 \sim 100 \mathrm{~Hz}$ and $1 \%$ strain amount. Specimens with a thickness of $2.0 \mathrm{~mm}$ and a diameter of $30 \mathrm{~mm}$ were fabricated by compression-molding at $255^{\circ} \mathrm{C}$. The cone calorimeter experiments (ISO 5660) were accomplished on specimens located horizontally with a rate of $30 \mathrm{~kW} / \mathrm{m}^{2}$ to evaluate the flammability of the nanocomposites.

\section{RESULTS AND DISCUSSION}

Figure 1 shows the TGA test outcomes for PA6, RGO, and PA6-RGO nanocomposites. The thermal steadiness of RGO, PA6-RGO, and PA6 may be categorized with TGA testing. It is obvious that RGO is not thermally durable and displays the major mass loss of $11.85 \mathrm{wt} \%$ on the scale from $100^{\circ} \mathrm{C}$ to $205^{\circ} \mathrm{C}$ as a result of deterioration of oxygen-holding chemical functions and production of $\mathrm{CO}_{2}, \mathrm{CO}$, and $\mathrm{H}_{2} \mathrm{O}$. The ultimate thermal degradation of $22.86 \%$ at $800^{\circ} \mathrm{C}$ occurs due to the elimination of additional oxygen functionalities $[35,36]$. Associated with RGO, the deterioration procedure had no significant alteration for the specimen of PA6-RGO up to $310^{\circ} \mathrm{C}$. There are two steps to the deterioration process for PA6RGO nanocomposites. The initial deterioration step in the scale from $100^{\circ} \mathrm{C}$ to $310^{\circ} \mathrm{C}$ is begun via the elimination of functional groups of hydroxyl from the RGO surface. The weight degradation is much smaller than that of RGO at a similar temperature, and greater thermal steadiness is caused by reactively intercalated PA6 links and intermolecular hydrogen-bond interaction among RGO layers and PA6 links. At the second deterioration step on a scale of $310-480^{\circ} \mathrm{C}$, the mass loss of PA6-RGO is huge and superior to that of RGO as a result of the deterioration of PA6. It is obvious that, though RGO has weak thermal steadiness, its PA6 nanocomposites are thermal-

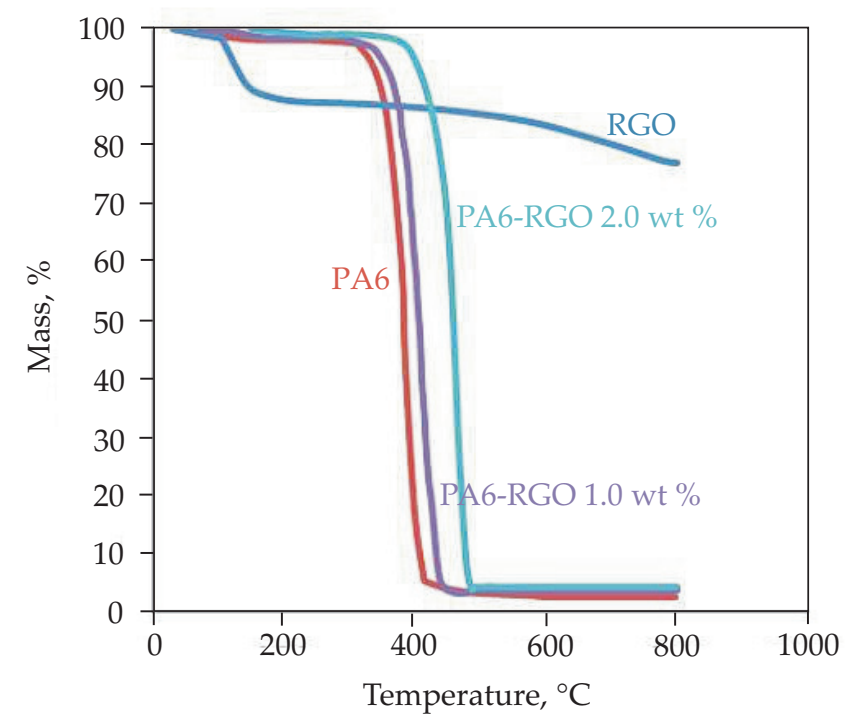

Fig. 1. TGA analysis outcomes for PA6, RGO, and PA6-RGO nanocomposites 
ly durable. Remarkably, the quantities of remaining char of PA6 were increased with the existence of RGO nano-layers. RGO is effective in accelerating the char development of PA6, because in a char of $6.8 \%$ with only $2.0 \mathrm{wt} \%$ of graphene, it is more than two times superior than graphene load. GO is able to accelerate the char development of PA6. As RGO loading in PA6-RGO 2.0 wt \% nanocomposite and the remaining char is $6.8 \%$. The increased char development indicates that the RGO inclusions reveal the potential in upgrading the fire-retardancy of PA6 [5-7].

Figure 2 presents the torque alterations of PA6 and PA6-RGO nanocomposite in the blending procedure. The melting PA6 was mixed with different levels of RGO inclusion. The primary torque of the feeding point for PA6 is $46 \mathrm{~N} / \mathrm{m}$, and with the delaying of blending time, torque reduces to stabilizing torque in $85 \mathrm{~s}$. The space of the blending compartment is occupied completely with the material in viscous flow condition, causing a reduction in rotor rotational resistance and torque. For PA6-RGO $1.0 \mathrm{wt} \%$ and $2.0 \mathrm{wt} \%$ nanocomposites, the primary torque of feeding point $(75 \mathrm{~N} / \mathrm{m}$ and $90 \mathrm{~N} / \mathrm{m})$, stabilizing torque, and the time needed (140 s and $205 \mathrm{~s}$ ) to achieve the stabilizing torque rise correspondingly, which makes a fluidity reduction of PA6 molecular links, affected by steric barrier influence of RGO and interfacial interaction among RGO and PA6 structure.

Figure 3 displays the FT-IR spectrums of PA6, RGO, and PA6-RGO nanocomposite to show a surface structure of specimens. For PA6 fiber, the absorption points at $3085 \mathrm{~cm}^{-1}, 2922 \mathrm{~cm}^{-1}, 2854 \mathrm{~cm}^{-1}$ are associated with $-\mathrm{CH}_{2}$ stretching vibration. The characteristic points focused at $1625 \mathrm{~cm}^{-1}$ and $1541 \mathrm{~cm}^{-1}$ are associated with in-plane vibration of amide [26]. The FT-IR of PA6 shows the altered characteristic points allocated to PA. In the case of the RGO, the points about $1531 \mathrm{~cm}^{-1}$ and $1367 \mathrm{~cm}^{-1}$ are

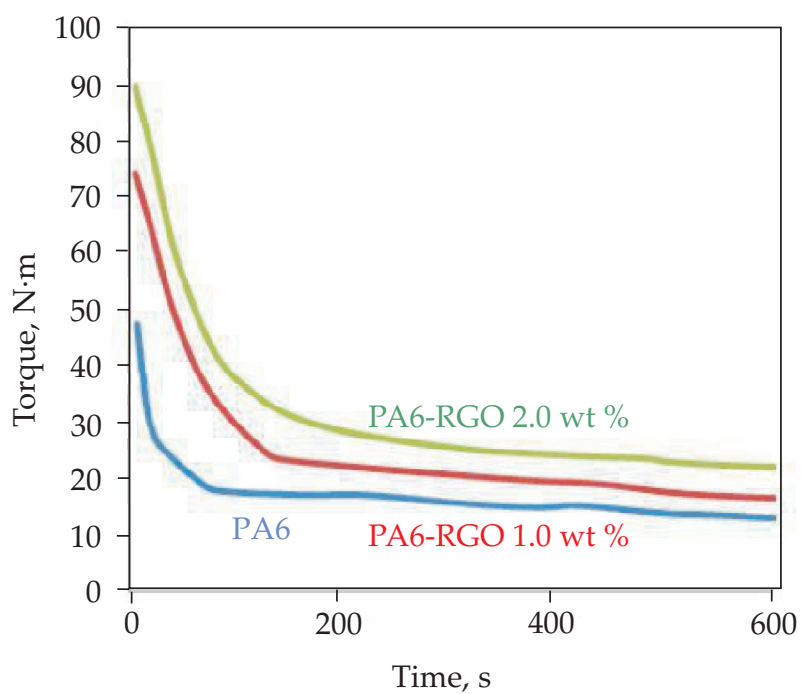

Fig. 2. Torque alterations of PA6, and PA6-RGO nanocomposite related to $-\mathrm{COOH}$ stretching vibration which is considerably reduced, disclosing that most GO was converted to RGO after warming at $85^{\circ} \mathrm{C}$ for $3 \mathrm{~h}$. The FT-IR of the PA6-RGO nanocomposites is designated at $1527 \mathrm{~cm}^{-1}$ and $1431 \mathrm{~cm}^{-1}$ and is related to C-C and C-N stretching vibrations, respectively. The characteristic points focused at $1290 \mathrm{~cm}^{-1}$ and $1021 \mathrm{~cm}^{-1}$ are allocated to C-H in-plane distortion. Meanwhile, the absorption point at $956 \mathrm{~cm}^{-1}$ was caused by C-H out-of-plane distortion vibration. Because of the small loading of the RGO, the RGO point may not be monitored obviously in Fig. 3.

Figure 4 exhibits the RS spectrums of PA6, RGO, and PA6-RGO nanocomposite to study the interaction among RGO layers and PA6 [24]. The characteristic G point is placed at $1588 \mathrm{~cm}^{-1}$ and initiates from elevated-frequency Raman active phonons and in-plane optical mode. The D point is located at $1328 \mathrm{~cm}^{-1}$ and is relevant to the disarrangement since it needs a flaw in six-atom rings for activation [12]. $I_{\mathrm{D}} / I_{\mathrm{G}}$ proportion enhances growth in flaws thanks to extra elastic spreading, though upon achieving a point where a huge number of flaws exist, the $I_{\mathrm{D}} / I_{\mathrm{G}}$ proportion is reduced through a more amorphous carbon configuration weaken point [15]. There are two points in the RS within 1000-2010 $\mathrm{cm}^{-1}$ for specimens of RGO and PA6-RGO: D point (1347-1351 $\mathrm{cm}^{-1}$ ) attributed to breathing mode of k-point phonons of $A_{1 g}$ symmetry because of disorderly proportions, $\mathrm{G}$ point $\left(1570-1575 \mathrm{~cm}^{-1}\right)$ related to the first-order spreading of $E_{2 g}$ phonons associated to a graphitic arrangement. This red shift phenomenon indicates that there can be an interaction among RGO and PA6 links [18] that is in harmony with FT-IR testing. A point at $2928 \mathrm{~cm}^{-1}$ matching with absorption point of $-\mathrm{CH}_{2}$ - in PA6 appears in RS of PA6-RGO, showing the presence of PA6 links on RGO layers. The proportion value of $\left(I_{\mathrm{D}} / I_{\mathrm{G}}\right)$ is attributed to messy-ordered assembling constructions of carbon [19]. The $I_{\mathrm{D}} / I_{\mathrm{G}}$ of PA6-RGO (1.02)

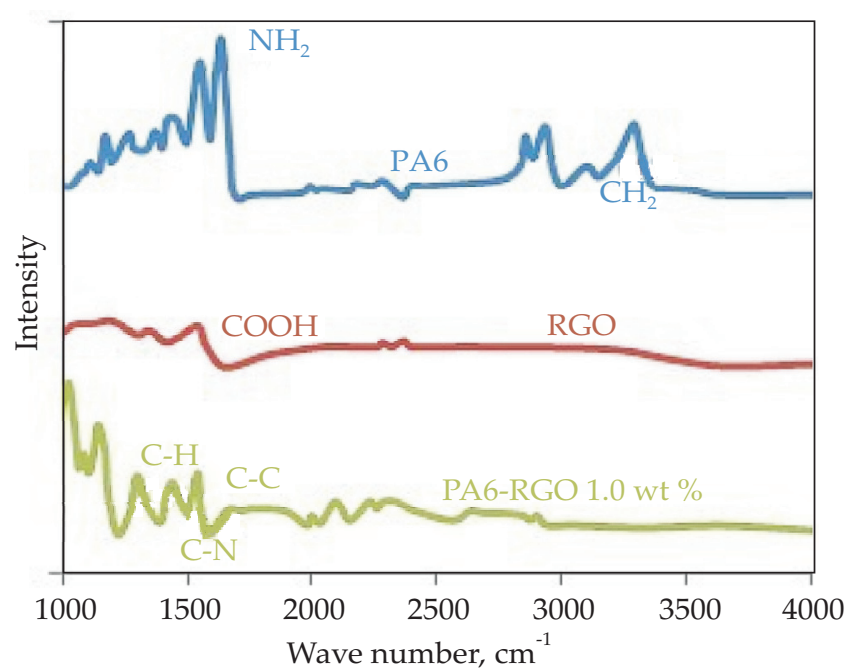

Fig. 3. FT-IR spectrums of PA6, RGO, and PA6-RGO nanocomposite 


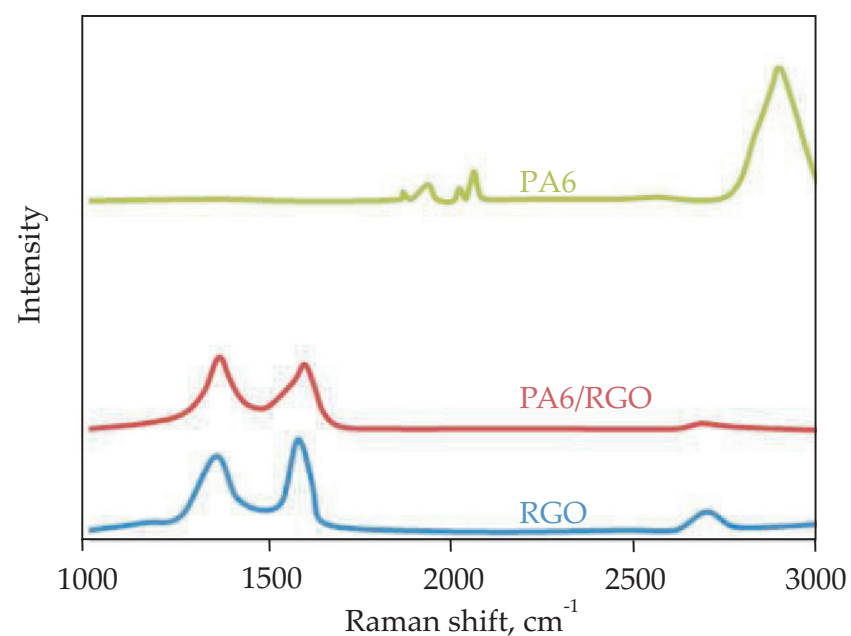

Fig. 4. RS alterations of PA6, RGO, and PA6-RGO nanocomposite

is similar to that of RGO (0.98) showing that the inclusion of RGO into PA6 reduces the crystallinity degrees $[10,11]$.

Figure 5 and Table 1 reveal the XRD spectrums of PA6, RGO, and PA6-RGO nanocomposites. XRD testing is accomplished to assess the crystal structure of PA6 and PA6-RGO nanocomposites. As indicated in Fig. 5, the representative diffraction point of the RGO, a wide point focused at $24.5^{\circ}$ that relates to (002) was monitored, revealing that the attained specimen was composed of arbitrarily arrayed RGO sheets with an uneven form [12]. For PA6, monitored diffractions at $2 \theta=20^{\circ}$ and $23^{\circ}$ are attributed to $\alpha_{1}$ and $\alpha_{2}$ crystalline structure and are labeled as (200) and (002/202) reflections correspondingly [23]. It may be monitored that there are no further diffraction points in XRD of PA6-RGO nanocomposites excluding diffraction points assigned to the PA6 phase, signifying that RGO does not any effect on the crystal structure of PA6. But, the diffraction peaks sites and intensity in nanocomposites alter a bit, showing that the inclusion of RGO has a minor effect on the crystal grain extent of nanocomposites. Besides, no obvious point was monitored to the accumulation of RGOs, showing that stacking of RGO in PA6 structure is not ordered and near to single-sheet level. The crystallinity $\left(X_{c^{\prime}} X R D\right)$ and crystal extend $\left(L_{h l k}\right)$ are obtained by the below formulas, accordingly:

$$
X_{c}=\left(\frac{I_{c}}{I_{c}+I_{a}}\right) \cdot 100 \%
$$

$I_{c}$ is a region below the crystalline alteration diagram and $I_{\mathrm{a}}$ is the region below the amorphous alteration diagram.

$$
\text { Scherrer formula } L_{\mathrm{hlk}}=\frac{k \lambda}{\beta \cos \theta}
$$

Where $L_{\text {hlk }}$ is an extend of crystallites obtained from a normal direction of hlk plane; $k$ is Scherrer constant $(k=0.88) ; \lambda$ is radiation wavelength, close to $0.155 \mathrm{~nm}$ in this example and $\beta$ is the full width of half top of diffraction point (hlk); $\theta$ is Bragg angle.

As indicated in Table 1, the crystallinity of the nanocomposites rises, with the inclusion RGO at $2.0 \mathrm{wt} \%$ content, and then reduces with the growth of RGO load, that satisfies properly with non-isothermal DSC outcomes, although crystal grain extension of nanocomposites indicates a tendency of the primary reduction and then rise. As it was revealed in part of the self-nucleation testing, RGO participated in the character of utilizing the crystallization of the PA6 structure mostly through speeding up the development of crystal nuclei, which was reflected in the substantial growth of the number of crystal nuclei. As a result, the size of grain raised from a crystal nucleus gets finer, with the growth of RGO load, achieving the smallest size with RGO inclusion of $2.0 \mathrm{wt} \%$. With the additional growth of the RGO load, the nucleation effect is weakened because of the accumulation of the RGO, causing a small growth of the size of the crystal grain.

Figure 6 demonstrates the electric conductivity of PA6 and PA6-RGO nanocomposites. For PA6-RGO nanocomposites, a sudden rise of about 6 orders of magnitude in electrical conductivity is monitored on a narrow scale with RGO load from 0 to $0.5 \mathrm{wt} \%$. It may be noticed that the electric conductivity of nanocomposites rises quickly with RGO content, and even with the inclusion of $1.0 \mathrm{wt} \% \mathrm{RGO}$, the nanocomposite alters from an insulator to semiconductor, showing a wonderful conductive link slightly generated at RGO loadings close to the percolation threshold. With additional rise of RGO up to $2.0 \mathrm{wt} \%$ loading, the growing level of nanocomposite conductivity reduces slightly, showing a great conductive link generated at upper RGO loading. Above $2.0 \mathrm{wt} \% \mathrm{RGO}$, the conductivity has finally

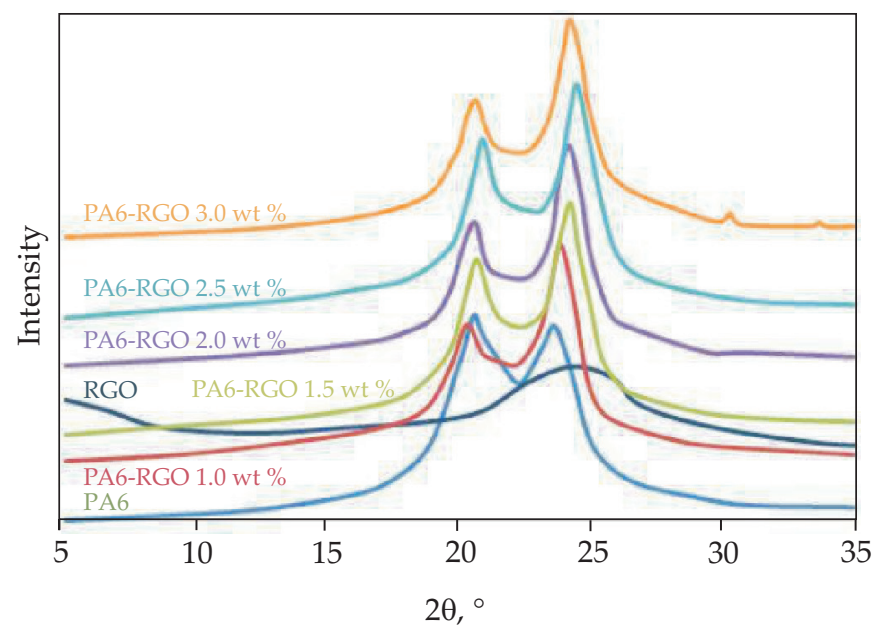

Fig. 5. XRD spectrums of PA6, RGO, and PA6-RGO nanocomposites 
T a b 1 e 1. XRD of PA6/RGO nanocomposites with different RGO loadings

\begin{tabular}{|c|c|c|c|c|}
\hline \multirow{2}{*}{ RGO, wt \% } & \multicolumn{2}{|c|}{ Angle $2 \Theta$} & \multirow{2}{*}{$\begin{array}{l}X_{c} \\
\%\end{array}$} & \multirow{2}{*}{$\begin{array}{c}\text { Grain extend } \\
\AA\end{array}$} \\
\hline & $\alpha_{1^{\prime}}^{\circ}$ & $\alpha_{2^{\prime}}^{\circ}$ & & \\
\hline 0.0 & 20.43 & 23.55 & 22.48 & 65.1 \\
\hline 1.0 & 20.25 & 23.61 & 23.71 & 59.2 \\
\hline 1.5 & 20.50 & 23.88 & 23.97 & 56.1 \\
\hline 2.0 & 20.34 & 23.84 & 25.04 & 54.3 \\
\hline 2.5 & 20.61 & 24.12 & 24.12 & 55.4 \\
\hline 3.0 & 20.55 & 23.97 & 23.28 & 58.5 \\
\hline
\end{tabular}

enhanced to equilibrium amount, reaching the higher point of $1.15 \cdot 10^{-2} \mathrm{~S} / \mathrm{m}$ with $3.0 \mathrm{wt} \%$ RGO load, which shows the final development of the ideal conductive link. Therefore, the electric conductivity of nanocomposites enhanced quickly to equilibrium amount, causing the development of the appropriate conductive link at this content of RGO.

Figure 7 reveals the thermal conductivity alterations of PA6 and PA6-RGO nanocomposites. The nanocomposites with appropriate thermal conductivity have many uses in thermal interface substances, connectors, and other elevated-performing thermal managing systems [16]. The thermal conductivity of nanocomposites enhances are consistent with enhancing RGO load. The thermal conductivity of PA6-RGO nanocomposite loading $3.0 \mathrm{wt} \%$ RGO enhances by $62 \%$ [from 0.31 to $0.5 \mathrm{~W} /(\mathrm{m} \cdot \mathrm{K})$ ] associated with PA6. In nanocomposites, as thermal energy is moved mostly in form of phonons, weak coupling in vibration modes on the filler-polymer interface conveys substantial thermal resistance [28]. Chemical bonding among the filler and the polymer may effectively decrease the acoustic phonon spreading at the interface.

Figure 8 and Table 2 exhibit the DSC test outcomes for PA6, and PA6-RGO nanocomposites in endothermic (Fig. 8a) and exothermic (Fig. 8b) conditions. DSC data displayed in Fig. 8 exhibits that for control PA6 and PA6-RGO $1.0 \mathrm{wt} \%$ an exothermic point is monitored among 210 and $230^{\circ} \mathrm{C}$, with locations at $224^{\circ} \mathrm{C}$ and $226^{\circ} \mathrm{C}$, correspondingly. This summit point is attributed to the melting point of substance [16], especially melting of $\mathrm{V}$ phase crystals

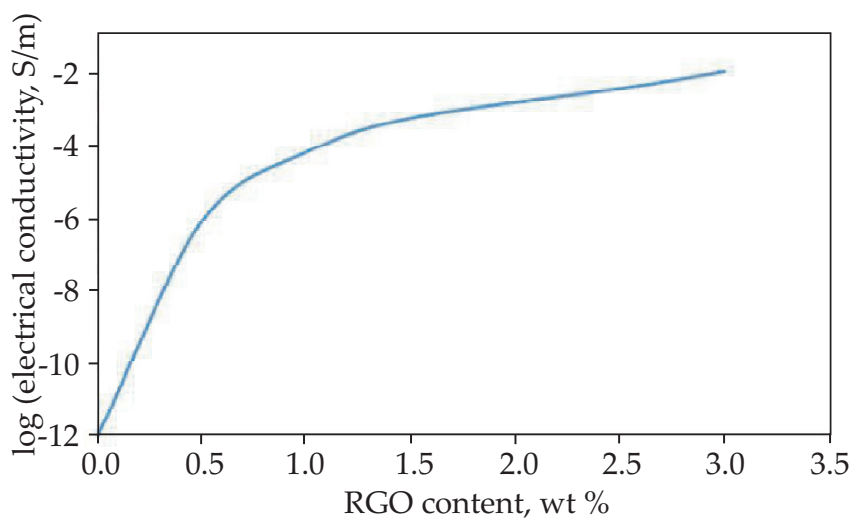

Fig. 6. Electrical conductivity of PA6, and PA6-RGO nanocomposites
[36]. The $2^{\circ} \mathrm{C}$ smaller melting temperature of bound PA6 in RGO that is associated with the nanocomposites and control polymer is probable cause of the length of PA6 links grafted onto the RGO surface and is monitored to be caused by Gr hindering the link spread in PA6, causing a smaller molecular weight [26]. The physical characteristics of crystalline polymers are directed by supermolecular morphology that consecutively is regulated by crystallization procedure [20, 21]. Therefore, the research of crystallization performance is essential for creating structure-property correlations in PA6-RGO nanocomposites. The non-isothermal DSC alterations of PA6 and PA6-RGO nanocomposites at a warming and cooling level of $15^{\circ} \mathrm{C} / \mathrm{min}$ are shown in Fig. 8, from that crystallization temperature $\left(T_{c}\right)$, melting temperature $\left(T_{m}\right)$, half-point width $(\Delta W)$, and crystallinity ( $X_{c^{\prime}}$ DSC) may be resulted, as exist in Table 2. Table 2 indicates that alterations of $T_{m}$ for PA6 in nanocomposites are not very clear, although, $T_{c}$ of PA6 enhances as loading of RGO enhances till to $2.0 \mathrm{wt} \%$ and then reduces. The super-cooling $\left(T_{m}-T_{c}\right)$ reduces at first and then enhances. The crystallinity $\left(X_{c}\right)$ of PA6 shows the trend of first enhancing, achieving the highest point at $2.0 \mathrm{wt} \%$ load of RGO and then reducing, showing the nucleation influence of RGO on PA6 as a heterogeneous nucleating chemical factor at a smaller RGO load [23]. With additional growth of RGO load, abruptly enhancing the viscosity of the system reduces the mobility of the PA6 link and inhibits the shaping of huge crystalline domains due to restricted space and sturdy limits imposed on PA6 links, which causes a reduction of $X_{c}$.

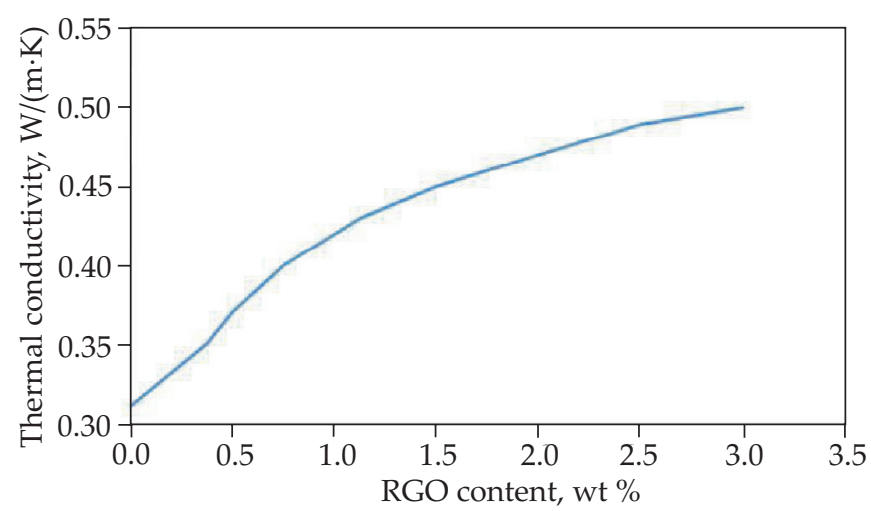

Fig. 7. Thermal conductivity alterations of PA6, and PA6RGO nanocomposites 
T a b l e 2. Non-isothermal DSC outcomes of PA6/RGO nanocomposites with different RGO loadings

\begin{tabular}{|c|c|c|c|c|c|}
\hline RGO, wt \% & $T_{m^{\prime}}{ }^{\circ} \mathrm{C}$ & $T_{m}-T_{c^{\prime}}{ }^{\circ} \mathrm{C}$ & $T_{C^{\prime}}{ }^{\circ} \mathrm{C}$ & $\Delta W,{ }^{\circ} \mathrm{C}$ & $X_{C^{\prime}} \%$ \\
\hline 0.0 & 218.7 & 33.8 & 184.9 & 11.3 & 22.48 \\
\hline 1.0 & 218.9 & 27.8 & 191.1 & 12.2 & 23.71 \\
\hline 1.5 & 219.6 & 26.8 & 192.8 & 10.5 & 23.97 \\
\hline 2.0 & 220.3 & 25.6 & 194.7 & 11.3 & 25.04 \\
\hline 2.5 & 219.8 & 25.7 & 194.1 & 11.0 & 24.12 \\
\hline 3.0 & 219.9 & 26.8 & 193.1 & 11.0 & 23.28 \\
\hline
\end{tabular}

The cone calorimeter test outcomes for PA6 and PA6-RGO nanocomposites, formulated by melt mixing are displayed in Figs. 9, 10, and Table 3. It may be monitored that PA6 fires quickly after burning and a peak of heat release rate $(P H R R)$ amount is $663 \mathrm{~kW} / \mathrm{m}^{2}$. The inclusion of RGO (1.0 and 2.0 wt \%) into PA6 reduces the PHRR to 588 and $545 \mathrm{~kW} / \mathrm{m}^{2}$. From Fig. 10, the total heat release $(T H R)$ alterations show the same tendency as heat release rate $(H R R)$, and THR values of PA6-RGO are decreased from $142.6 \mathrm{MJ} / \mathrm{m}^{2}$ (PA6) to 113.6 and $102.5 \mathrm{MJ} / \mathrm{m}^{2}$. From Table 3, it may be noticed that the inclusion of the RGO has a small effect on the time-to-ignition (TTI) of the nanocomposites, due to the low contents. Concerning the total smoke production (TSP), all the specimens loading RGO show superior TSP associated with PA6. This phenomenon is probably caused by the incomplete combustion of PA6. RGO is not permeable to any gas molecules. The two-dimensional construction of RGO inside the PA6 forms a tortuous path that deters the molecular diffusion through the PA6 and accordingly reduces penetrability. The orientation of the platelets increases the barrier characteristics perpendicular to their alignment, while the upper platelet aspect correlates with increased barrier resistance. So, the inclusion of RGO increases the gas barrier characteristics of PA6. The fire-retardant characteristic of PA6 nanocomposites has become a serious concern in industrial areas. Thanks to its endothermic and strong layered structure, Gr performs like physical barriers to decrease the diffusion of gases and deterioration of products, hence prevents the supply of oxygen and plays the role of fire-retardant. The degree of spread and inter-

a)

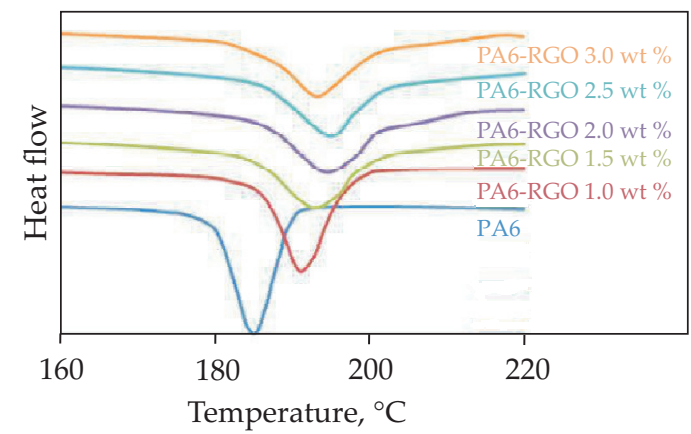

facial interactions among RGO and polymers are major factors for progress in fire-retardancy of nanocomposites.

Figures 11, 12, and 13 demonstrate the complex viscosity, elastic modulus, and viscous modulus tests outcomes for PA6, and PA6-RGO nanocomposites. The molecular link tangle performance of PA6 nanocomposites with different RGO loading was searched by dynamical rheological outcomes. The complex viscosity like a variable of frequency denotes a pseudo-plastic fluid feature of PA6 flow performance which was monitored [4]. The small-frequency complex viscosity enhances considerably in the existence of RGO particularly above $2.0 \mathrm{wt} \%$, and the Newtonian plateau of viscosity alterations vanishes slowly, indicating an outstanding shear-thinning performance [5]. Figures 12 and 13 show the elastic modulus $\left(G^{\prime}\right)$ and viscous modulus $\left(G^{\prime \prime}\right)$ of specimens with various RGO loadings. At small frequencies, PA6 displays a conventional polymer terminal performance with scaling characteristics of $G^{\prime} \sim \omega^{1.3}$ and $G^{\prime \prime} \sim \omega^{0.87}$ because of its entirely stress-free polymer links [6]. The RGO loading leads to sudden enhances in both $G^{\prime}$ and $G^{\prime \prime}$ and the terminal performance at small frequencies vanishes with $2.0 \mathrm{wt} \%$ load of the RGO. Based on the pronounced alterations of $G^{\prime}$ and $G^{\prime \prime}$, it is surmised that terminal to non-terminal alteration for PA6-RGO nanocomposites, is proving a development of interconnecting link of RGO nano-layers in nanocomposites. The frequency dependence of $G^{\prime}$ at small frequencies falls with the growth of RGO loads. At RGO loads higher than $2.0 \mathrm{wt} \%$, the approximate frequencyindependence of $G^{\prime}$ directs the alteration from liquid-state to solid-state rheological performance.

b)

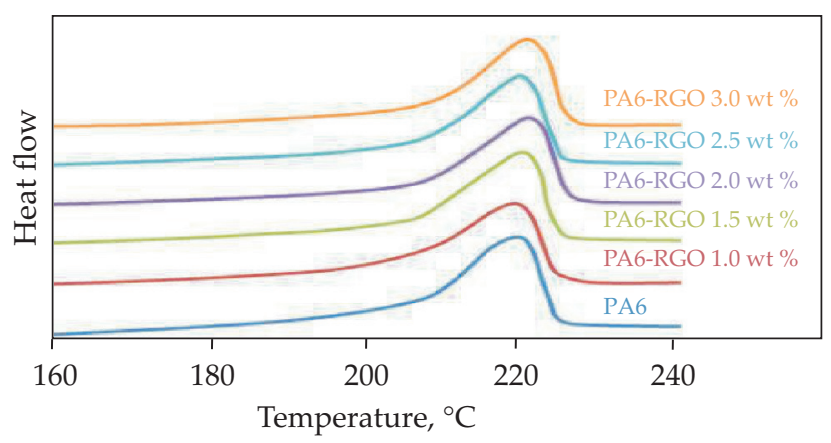

Fig. 8. DSC analysis outcomes for PA6, and PA6-RGO nanocomposites, a) endothermic, b) exothermic 
T a b 1 e 3. Cone analysis outcomes for PA6 and PA6/RGO

\begin{tabular}{|c|c|c|c|c|}
\hline Specimens & $\begin{array}{l}\text { PHRR } \\
\mathrm{kW} / \mathrm{m}^{2}\end{array}$ & $\begin{array}{c}\text { THR } \\
\mathrm{MJ} / \mathrm{m}^{2}\end{array}$ & $\begin{array}{c}\text { TTI } \\
\mathrm{s}\end{array}$ & $\begin{array}{c}\text { TSP } \\
\mathrm{m}^{2} / \mathrm{m}^{2}\end{array}$ \\
\hline PA6 & 663 & 142.6 & 110 & 4.26 \\
\hline PA6-RGO $1.0 \mathrm{wt} \%$ & 588 & 113.6 & 107 & 4.72 \\
\hline PA6-RGO $2.0 w t \%$ & 545 & 102.5 & 102 & 4.89 \\
\hline
\end{tabular}

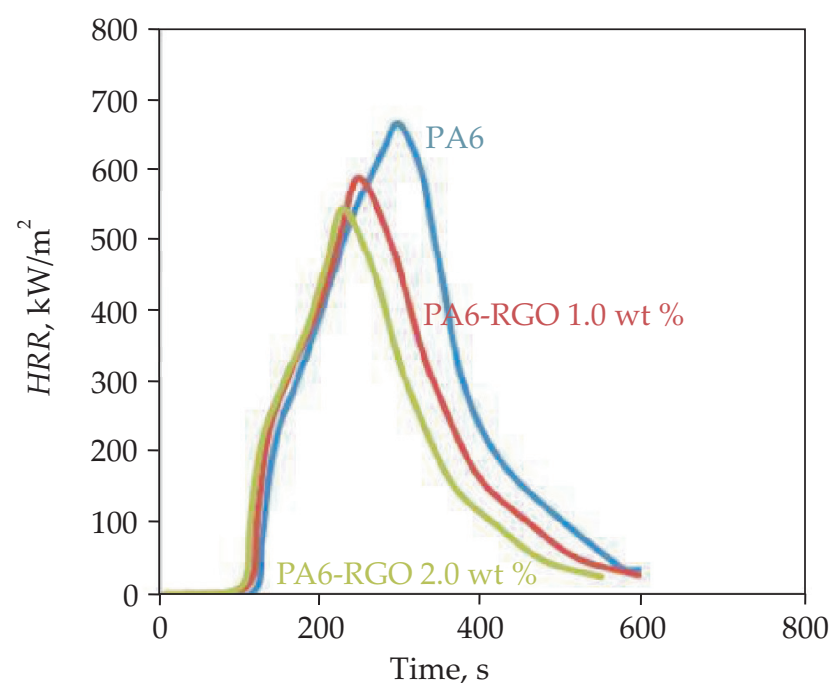

Fig. 9. HRR test outcomes for PA6, and PA6-RGO nanocomposite

Figure 14a indicates SEM depiction on a cross-section of hot-pressed the PA6. To assess the general spread and exfoliation of RGO nano-layers in PA6 directly, Fig. 14b indicates the SEM photo of the freeze-fractured surface of the PA6-RGO nanocomposite. It is monitored that RGO nano-layers were exfoliated and spread properly in nanocomposite structure and no huge coagulates existed. The exfoliation of RGO allows the development of an interconnected 3D-dimensional conducting link in the polymer structure. Hence, the electric conducting characteristic of the PA6-RGO nanocomposite with a small percolation threshold may be related to stabled exfoliation and spread of thermally RGO nano-layers in the PA6 structure. Moreover, even spread of the exfoliated RGO nanolayers was attained, which is associated with the fact that

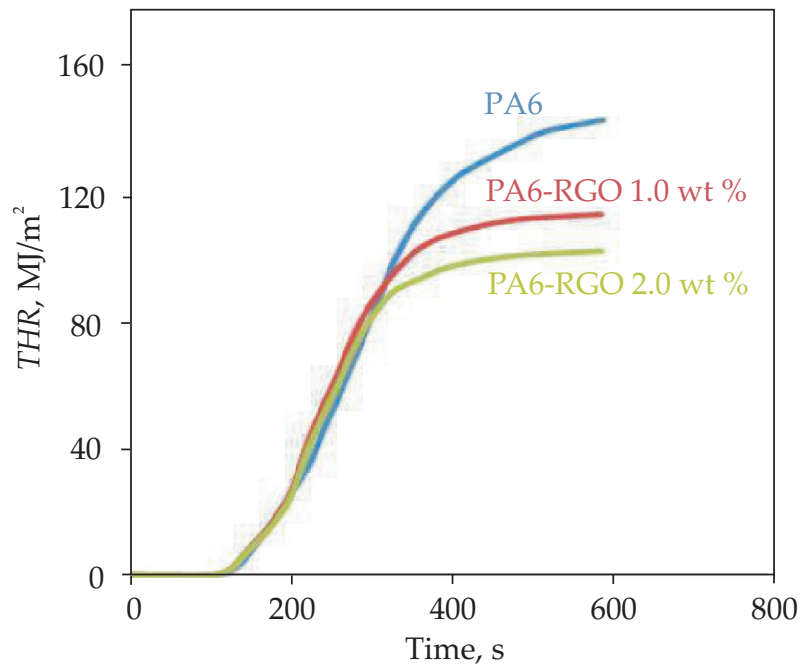

Fig. 10. THR analysis outcomes for PA6, and PA6-RGO nanocomposite

RGO still bore some remaining polar chemical functional groups on the RGO surface; however, it practiced a thermal reduction at $1055^{\circ} \mathrm{C}[9]$ that enabled and stabled spread of RGO nano-layers in polar PA6 structure. TEM is applied to deliver immediate signs-on development of electric conductive link of RGO (the black area) inside PA6 (the white area). A further concentrated electric conductive link results in the nanocomposite with a percolation threshold of $2.0 \mathrm{wt} \%$ in Fig. 14c. The development of the conductive pathways at such a small RGO load is produced by reactive intercalation of PA6 molecules in RGO nano-layers that advance the spread of RGO in the PA6 structure. At an upper content $(3.0 \mathrm{wt} \%)$, the RGO nano-layers are linked to generate an appropriate and following conductive pathway inside the polymer structure in Fig. 14d.

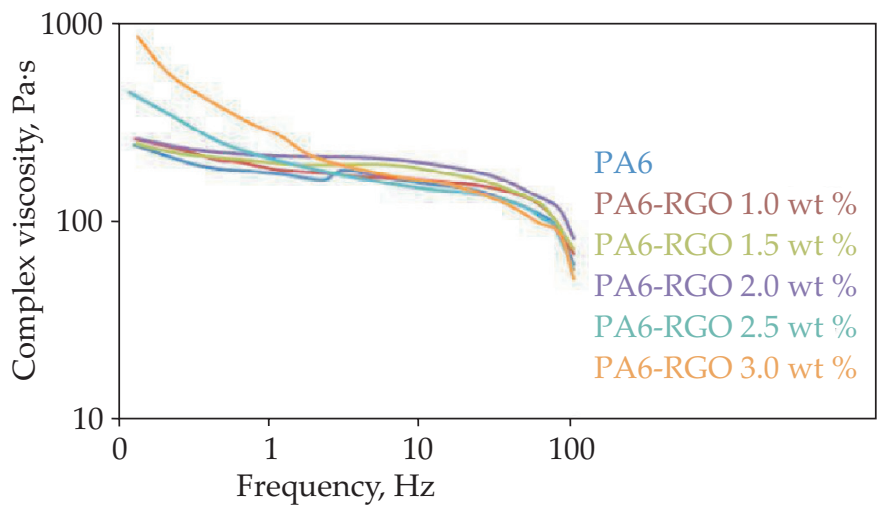

Fig. 11. Complex viscosity test outcomes for PA6, and PA6-RGO nanocomposites 


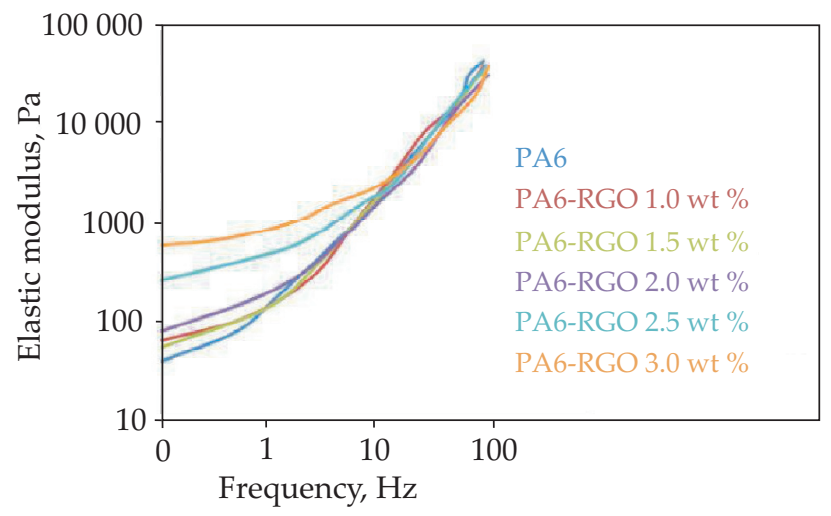

Fig. 12. Elastic modulus test outcomes for PA6, and PA6-RGO nanocomposites

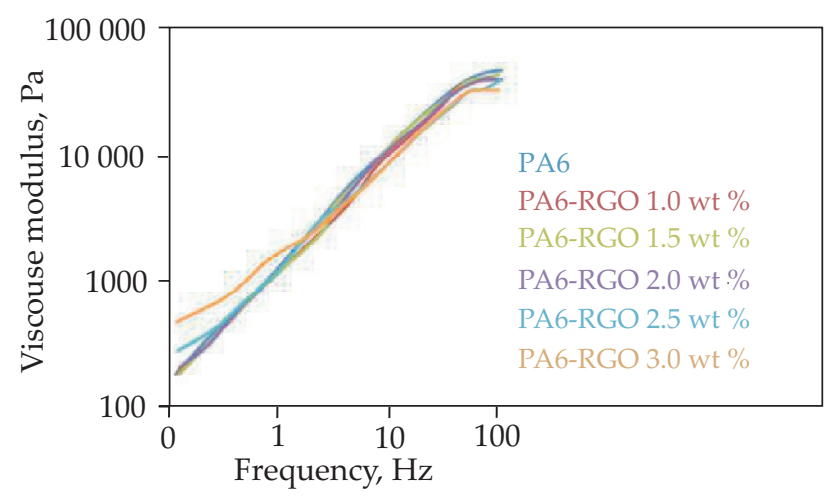

Fig. 13. Viscous modulus test outcomes for PA6, and PA6RGO nanocomposites

PA6

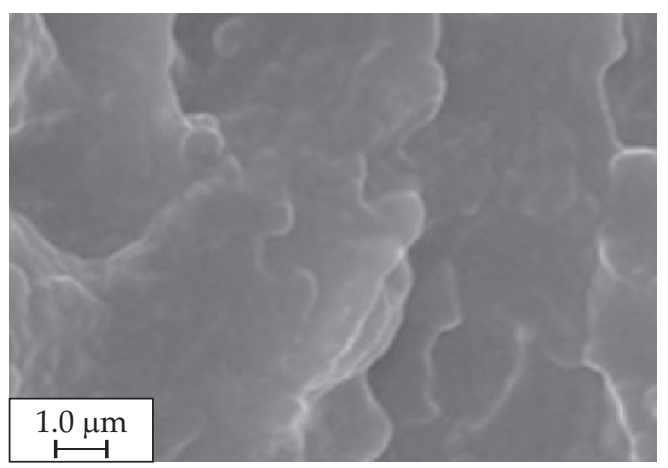

PA6-RGO $2.0 \mathrm{wt} \%$

c)

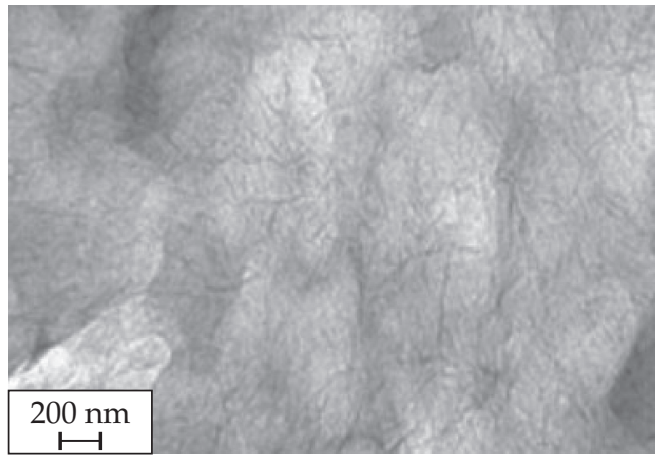

\section{CONCLUSIONS}

PA6-RGO nanocomposites were formulated via the melt-mixing procedure. The influence on the development of crystallization and link structure on electric conductive characteristics of nanocomposites was studied. Frequency-independence of $G^{\prime}$ and then abruptly decreased phase angle at the small-frequency area with a load of $2.0 \mathrm{wt} \%$ indicates the change from liquid-state to solid-state rheological performance. Dynamic percolation performance of nanocomposites was searched and it was indicated that thermal conductivity, electric conductivity, and mechanical characteristics of nanocomposites were enhanced with the development of the electric conductive link. Other characteristics like thermal steadiness and fire-retardancy were also showing progress of nanocomposites with the extremely small loading of the RGO. The covalently bonded RGO nanostructures successfully improved the fire-retardant characteristics as the fillers in PA6 from the PHRR and THR outcomes. A morphological analysis displayed that RGO was spread well in PA6. Our outcomes indicate that the progress in fire-retardancy of RGO nanocomposite may be caused by the barrier effect of its link. The RGO nanocomposites open up a new strategy to be applied towards a wide range of polymer materials as an effective filler to advance the flame-safety of polar polymers. However, the current outcomes have shown that RGO is extremely hopeful for the future applications of industrial polymers.

b)

PA6-RGO 2.0 wt \%

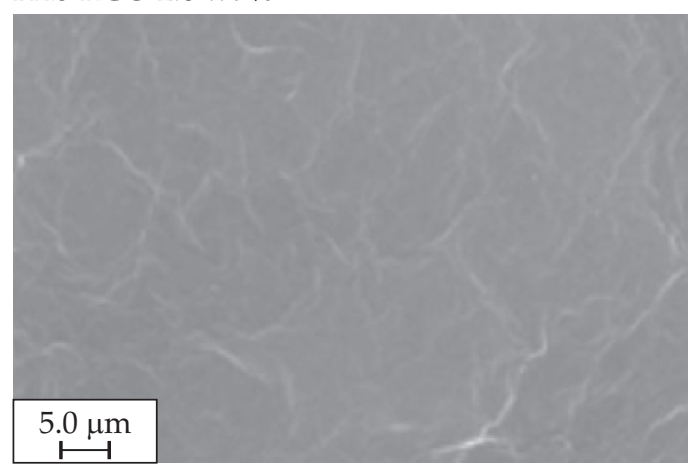

PA6-RGO 3.0 wt \%

d)

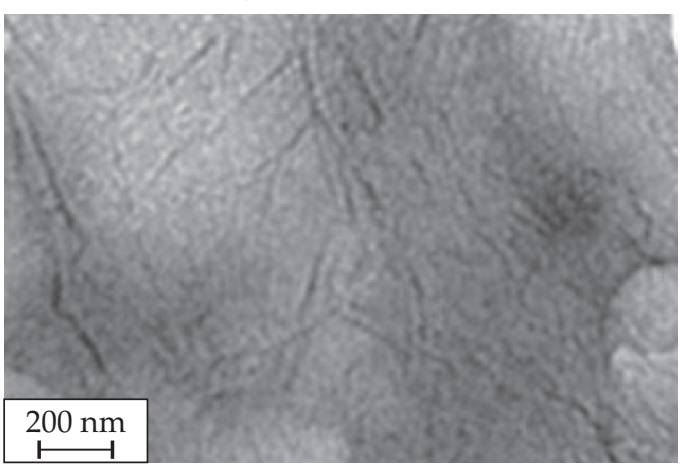

Fig. 14. SEM of: a) PA6, b) PA6-RGO 1.0 wt \%; TEM of: c) PA6-RGO 2.0 wt \%, d) PA6-RGO 3.0 wt \% 


\section{REFERENCES}

[1] O'Neill A., Bakirtzis D., Dixon D.: European Polymer Journal 2014, 59, 353.

https://doi.org/10.1016/j.eurpolymj.2014.07.038

[2] Xiang M., Li C., Ye L.: Journal of Industrial and Engineering Chemistry 2018, 62, 84.

https://doi.org/10.1016/j.jiec.2017.12.047

[3] Fu X., Yao C., Yang G.: RSC Advances 2015, 5, 61688. http://dx.doi.org/10.1039/C5RA09312K

[4] Li L.L., Chen S.H., Ma W.J. et al.: eXPRESS Polymer Letters 2014, 8 (6), 450. http://dx.doi.org/10.3144/expresspolymlett.2014.48

[5] Wang Y., Qing X., Quan Zhou Q. et al.: Biosensors and Bioelectronics 2017, 95, 138. https://doi.org/10.1016/j.bios.2017.04.018

[6] Xiang M., Yang R., Yang J. et al.: Composites Part B 2019, 167, 533.

https://doi.org/10.1016/j.compositesb.2019.03.033

[7] Xiang M., Li C., Ye L.: Journal of Polymer Research 2019, 26, 104. https://doi.org/10.1007/s10965-019-1765-x

[8] Hong N., Song L., Hull T.R. et al:: Materials Chemistry and Physics 2013, 142, 531. https://doi.org/10.1016/j.matchemphys.2013.07.048

[9] Song N., Yang J., Ding P. et al.: Composites Part A 2015, $73,232$. https://doi.org/10.1016/j.compositesa.2015.03.018

[10] Hwang S.H., Kim B.J., Baek J.B. et al.: Composites Part B 2016, 100, 220. https://doi.org/10.1016/j.compositesb.2016.06.062

[11] Saleh T.A., Sari A., Tuzen M.: Chemical Engineering Journal 2017, 307, 230. https://doi.org/10.1016/j.cej.2016.08.070

[12] Zhou S., Wang J., Wang S. et al.: Materials Chemistry and Physics 2018, 217, 315. https://doi.org/10.1016/j.matchemphys.2018.06.080

[13] Ren Y., Zhang Y., Guo H. et al.: Composites Part A 2019, 126, 105578.

https://doi.org/10.1016/j.compositesa.2019.105578

[14] Paseta L., Alled J.M.L., Malankowska M. et al.: Separation and Purification Technology 2020, 247, 116995. https://doi.org/10.1016/j.seppur.2020.116995

[15] Ren Y., Ren L., Li J. et al.: Composites Science and Technology 2020, 199, 108340. https://doi.org/10.1016/j.compscitech.2020.108340

[16] Fu X., Zhao X., Li L. et al.: Composites Part C 2020, 2, 100043 https://doi.org/10.1016/j.jcomc.2020.100043

[17] Chen Y., Li D., Yang W., Xiao C.: Composites Part B 2018, 138, 55. https://doi.org/10.1016/j.compositesb.2017.09.058

[18] Sabet M., Soleimani H., Mohammadian E., Hosseini S.: Plastics, Rubber and Composites 2020, 50, 61. http://dx.doi.org/10.1080/14658011.2020.1833557
[19] Zhang Y., Lu Y., Yan X. et al.: Composites Part A 2019, $123,149$.

https://doi.org/10.1016/j.compositesa.2019.05.008

[20] Gomez J., Villaro E., Karagiannidis P.G., Elmarakbi A.: Results in Materials 2020, 7, 100105. https://doi.org/10.1016/j.rinma.2020.100105

[21] Sabet M., Soleimani H., Mohammadian E.: Iran Polymer Journal 2020, 29, 1099. https://doi.org/10.1007/s13726-020-00864-y

[22] Allahbakhsh A., Khodabadi F.N., Hosseini F.S., Haghighi A.H.: European Polymer Journal 2017, 94, 417. https://doi.org/10.1016/j.eurpolymj.2017.07.031

[23] Scaffaro R., Maio A.: Composites Part B 2020, 165, 55. https://doi.org/10.1016/j.compositesb.2018.11.107

[24] Sabet M., Soleimani H., Hosseini S.: High Performance Polymer 2020, 33, 165. https://doi.org/10.1177/0954008320943929

[25] Li R., Shi K., Ye L., Li G.: Composites Part B 2019, 162, 11.

https://doi.org/10.1016/j.compositesb.2018.10.091

[26] Sabet M., Soleimani H., Mohammadian E., Hosseini S.: Materials Performance and Characterization 2020, 9 (1), 284 https://doi.org/10.1520/MPC20190256

[27] Ding P., Su S., Song N. et al.: Carbon 2014, 66, 576. https://doi.org/10.1016/j.carbon.2013.09.041

[28] Zheng D., Tang G., Zhang H.B. et al.: Composites Science and Technology 2012, 72, 284. https://doi.org/10.1016/j.compscitech.2011.11.014

[29] Sabet M., Soleimani H., Hosseini S.: Bulletin of Materials Science 2020, 43, 38. https://doi.org/10.1007/s12034-019-2021-z

[30] Chiu F.C., Huang I.-N.: Polymer Testing 2012, 31, 953. https://doi.org/10.1016/j.polymertesting.2012.06.014

[31] Chatterjee S., Nüesch F.A., Chu B.T.T.: Chemical Physics Letters 2013, 557, 92. https://doi.org/10.1016/j.cplett.2012.11.091

[32] Wang Y.S., Li S.M., Hsiao S.T. et al.: Carbon 2014, 73, 87.

https://doi.org/10.1016/j.carbon.2014.02.043

[33] Cai Z., Meng X., Han Y. et al.: Composites: Part A 2015, 69, 115. https://doi.org/10.1016/j.compositesa.2014.11.011

[34] Sabet M., Soleiman H.: Polymer Science Series A 2019, $61,922$. https://doi.org/10.1134/S0965545X20010095

[35] Li X., Shao L., Song N. et al.: Composites Part A 2016, $88,305$. https://doi.org/10.1016/j.compositesa.2016.06.007

[36] Sabet M., Soleimani H., Hosseini S.: Polymer Bulletin 2020, 77, 459. https://doi.org/10.1007/s00289-019-02759-2

[37] Ma M., Zhu Z., Wu B. et al.: Materials Letters 2017, 190, 71. https://doi.org/10.1016/j.matlet.2016.12.140

Received 13 I 2021 